\title{
BIMBINGAN KELOMPOK UNTUK MENINGKATKAN PENYESUAIAN SOSIAL SISWA KELAS IX-E SMP NEGERI 1 WONOASRI KABUPATEN MADIUN
}

\author{
NINIK SUHARTI \\ nnksuharti@gmail.com
}

\begin{abstract}
Changes that occur in the community often felt too fast. As a result, there are people who are able to adjust and compensate for the change and some are not able to adapt itself. For those who are not able to adapt to the changing demands that will have problems in adjustment and social .In the process of social adjustment, students are exposed to the demands and expectations of a very complex and difficult. Many students feel hesitant and less responsive to the situation at hand. As a result of the difficulties to adapt themselves to the environment, eventually students perform actions that violate norms. Found a lot of students who perform inappropriate acts, violate school rules, late entry, ditching, brawl, and others. Group counseling is expected to answer these problems .

The results of observations in class IX - E SMP Negeri 1 Wonoasri found some students who have low levels of social adjustment in order to comply with the school that impact on learning outcomes is low.

This study uses action research (Classroom action research) to class IX E SMP Negeri 1 Wonoasri with the aim to help students improve their ability in school and social adjustment can adjust to social learning on a regular basis .

From the results of this study concluded that group counseling can improve the social adjustment of students effectively, Although there are some students who have not demonstrated a significant improvement or fall into the category of students who no change significantly and there are also students who showed a decline in understanding of themselves, this may be due to the problems it faces more difficult than the problems faced by other friends or because there is no desire in him to improve social adjustment .
\end{abstract}

Keywords : group counseling, social adjustment, action research

* Ninik Suharti adalah Guru BK SMP Negeri 1 Wonoasri Kabupaten Madiun. 


\section{Pendahuluan}

Perubahan yang terjadi di masyarakat dalam era globalisasi ini sering dirasakan terlalu cepat. Akibatnya ada orang yang mampu menyesuaikan diri dan mengimbangi perubahan tersebut dan ada pula yang tidak, sesuai dengan kemampuannya. Proses globalisasi terus berlangsung, informasi yang mengalir tidak mengenal batas, ruang, dan waktu. Akhirnya, bagi yang tidak mampu menyesuaikan dengan tuntutan perubahan itu, akan mengalami hambatan dalam penyesuaian diri/sosialnya, lebih tragisnya ia tidak mampu menyesuaikan dirinya dengan baik (maladjustment). Dalam konteks sekolah hal-hal seperti itu harus diantisipasi karena keadaan semacam ini akan turut berpengaruh dan akan dialami oleh para siswa. Proses perubahan yang terjadi di luar sekolah tetap akan memiliki dampak terhadap perilaku anak (siswa). Perilaku yang muncul sebagai akibat tidak dapat menyesuaikan dirinya adalah perilaku menyimpang.

Salah satu bentuk perilaku maladjustment di sekolah oleh Abin Syamsuddin (1999) dan S. Nasution (1988) disebut sebagai anak atau siswa terisolir (isolated children), yaitu siswa yang ditolak atau tidak disenangi oleh anggota kelompoknya. Muncul pertanyaan mengapa ada anak yang tidak disenangi atau ditolak di kelompoknya? Apa yang menjadi alasan sehingga seorang siswa dapat diterima atau dapat akrab dengan orang lain atau kelompoknya? Pada saat memasuki lingkungan baru, individu dituntut untuk dapat menyesuaikan dirinya dengan lingkungan tersebut, sehingga ia dapat hidup, tumbuh, dan berkembang serta dapat melangsungkan hidupnya. Begitu pula pada saat seorang siswa yang memasuki lingkungan sekolah yang baru siswa akan dihadapkan pada berbagai situasi dan kondisi yang baru yang berbeda dengan lingkungan sebelumnya.

Siswa dihadapkan pada berbagai tuntutan dan harapan yang sifat dan jenisnya lebih kompleks. Hal itu menuntut siswa untuk dapat melakukan penyesuaian dengan baik. Mereka dihadapkan dengan mata pelajaran baru, lingkungan sekolah yang baru, teman baru, guru-guru yang baru, dan lain-lain. Kondisi ini menuntut siswa untuk dapat menyesuaikan dirinya dengan baik. Individu tidak luput dari kemungkinan mengalami hambatan, masalah, tekanan (stress) dalam hidupnya. Untuk mencapai kondisi psikologis yang senantiasa 
sehat, penyesuaian diri mutlak diperlukan. Dalam hal ini Derlega \& Janda (1978: 28) mengemukakan: "Adjustment is a life long process, and people must continue to meet deal with the stresses and challenges of life in order to achieve a healthy personality".

Dalam melakukan penyesuaian dengan lingkungan, siswa terkadang dihadapkan pada kondisi sulit, misalnya: pertama, pola perilaku yang dikembangkan di rumah, hal ini menimbulkan kesulitan hubungan sosial di luar rumah; kedua, rumah yang kurang memberikan teladan yang baik pada perilaku anak; ketiga, kurangnya motivasi untuk belajar menyesuaikan diri. Hal ini banyak terjadi karena pengalaman sosial awal yang tidak menyenangkan; keempat, anak tidak mendapatkan bimbingan dan bantuan yang cukup dalam proses belajarnya. Elizabeth B. Hurlock (1992: 213) mengemukakan bahwa salah satu tugas perkembangan masa remaja yang tersulit adalah yang berhubungan dengan penyesuaian sosial. Remaja harus menyesuaikan diri dengan lawan jenis dalam hubungan yang sebelumnya belum pernah ada dan harus menyesuaikan dengan orang dewasa di luar lingkungan keluarga dan sekolah.

Dikatakan tersulit dalam menyesuaikan diri, menurut Elizabeth B. Hurlock karena meningkatnya pengaruh kelompok sebaya, perubahan dalam perilaku sosial, pengelompokan sosial yang baru, nilai-nilai baru dalam seleksi persahabatan, nilai-nilai baru dalam dukungan dan penolakan sosial, dan nilainilai baru dalam memilih pemimpin. Di samping itu, untuk mencapai tujuan dari pola sosialisasi dewasa, remaja harus membuat banyak penyesuaian baru.

Pada satu sisi, meluasnya kesempatan untuk membuka diri dalam berbagai kegiatan sosial, dapat memperluas wawasan sosial siswa (remaja). Individu akan dapat menilai temannya dengan lebih baik, sehingga penyesuaian diri dalam situasi sosial bertambah baik.

Berbagai cara ditempuh anak dalam menyesuaikan diri dengan lingkungannya. Salah satu cara yang dilakukan oleh siswa adalah memilih teman (interaksi dengan siswa lain), interaksi dengan guru, dan berinteraksi dengan lingkungan sekitarnya. Dengan mempunyai teman maka ia dapat melakukan interaksi sosial yang baik dengan lingkungan sekolah. Melalui interaksi sosial ini 
diharapkan dapat memperlancar proses belajar siswa, karena dengan interaksi sosial yang baik anak akan mendapat informasi tentang banyak hal dari lingkungannya. Melalui interaksi sosial, siswa belajar mengenai sikap yang bagaimana yang dapat diterima dengan baik oleh teman-temannya, diterima hanya sekedarnya saja atau ditolak oleh teman-temannya. Siswa juga dapat belajar tentang penilaian orang lain terhadap dirinya.

Masalah hubungan sosial merupakan salah satu kebutuhan manusia. Kebutuhan sosial ini perlu dipenuhi untuk mencapai kehidupan yang sehat, bergairah, dan penuh semangat, bebas dari rasa cemas. Namun demikian pemenuhan kebutuhan sosial ini akan banyak bergantung pada perilaku sosial individu yang bersangkutan. Setiap pergaulan dan interaksi sosial menuntut individu untuk berperilaku sosial yang sesuai dengan norma-norma yang berlaku dalam lingkungannya. Dengan terpenuhinya kebutuhan sosial akan mempengaruhi perilaku sosial individu. Perilaku sosial individu itu dibentuk melalui pengalaman yang diperoleh dari hasil interaksinya dengan orang lain. Sifat manusia yang berbeda-beda diperoleh dari hasil belajar melalui kontak dengan orang lain. Tidak ada kepribadian dan tidak ada perilaku manusia tanpa adanya interaksi dan partisipasi sosial (Hollander, 1974: 11).

Sulivan (Lindzey, 1981: 183 menyatakan bahwa "personality only manifests it self when the person is behaving in relation to one or more other individual."

Setiap orang tentu ingin efektif dalam melakukan hubungan dan interaksi sosialnya. Untuk itu setiap orang perlu memiliki kecakapan sosial yang memungkinkannya untuk dapat berada bersama orang lain dengan bijak dan penuh pengertian. Setiap orang hendaknya menyadari minat orang lain, menghargai tujuan hidupnya, serta menghormati harga dirinya.

Dari semua perubahan yang terjadi dalam sikap dan perilaku sosial, yang paling menonjol terjadi pada remaja seusia SMP adalah dalam hubungan dengan lawan jenis. Individu tidak lagi memilih teman berdasarkan kemudahannya entah di sekolah atau di lingkungan lainya sebagaimana terjadi pada masa kanak-kanak. Individu remaja sudah menginginkan teman yang mempunyai minat-minat dan 
nilai yang sama, yang dapat dimengerti dan membuatnya aman, dapat dipercaya, dan lain-lain.

Banyak siswa yang merasa ragu dan kurang responsif terhadap situasi yang harus dihadapinya. Merasa salah suai, tidak beruntung dalam pergaulan, yang pada akhirnya melakukan tindakan-tindakan yang melanggar norma-norma yang berlaku. Ditemukan banyak siswa yang melakukan perbuatan yang tidak pantas, berkelahi, mabuk-mabukan, merokok, perbuatan asusila, terlibat narkoba, dan berbagai bentuk perilaku maladjustment lainnya.

Bentuk-bentuk perilaku lainnya yang berkaitan dengan sekolah antara lain masih dijumpai di kalangan siswa SMP yang melanggar peraturan sekolah seperti melanggar tata tertib, terlambat masuk, membolos dan sebagainya, ini dapat mengakibatkan prestasi belajar mereka rendah. Dalam keadaan seperti inilah tugas pokok layanan bimbingan yaitu membantu siswa mengatasi hambatan-hambatan yang mengganggu dalam melaksanakan tugas-tugas belajarnya. Peraturan Pemerintah Nomor 29/90 pasal 27 secara tegas menjelaskan bahwa, “...bimbingan merupakan bantuan yang diberikan kepada siswa dalam rangka upaya menemukan pribadi, mengenal lingkungan, dan merencanakan masa depan".

Uraian di atas memperlihatkan peranan penting layanan bimbingan sebagai upaya yang terpadu dalam keseluruhan pendidikan di sekolah. Rochman Natawidjaja (1990: 16) menyatakan:

Bimbingan dan konseling memiliki fungsi dan posisi kunci dalam pendidikan di sekolah yaitu sebagai pendamping fungsi utama di sekolah dalam bidang pengajaran dan perkembangan intelektual siswa dalam menangani ihwal sisi pribadi sosial siswa di sekolah.

Pendapat tersebut dipertegas oleh Moh. Surya (1991: 3-4) bahwa pendekatan pendidikan hendaknya dilaksanakan secara terpadu. Melalui kegiatan instruksional tampaknya guru baru mampu menyentuh aspek-aspek intelektual saja, dan kurang menyentuh aspek-aspek non intelektual. Kegiatan tersebut lebih banyak bersifat masal dan klasikal, sehingga tak jarang kehidupan individual menjadi kurang terpedulikan. Oleh karena itu kegiatan instruksional perlu 
ditunjang dengan kegiatan interpersonal yakni pelaksanaan bimbingan dan konseling.

Upaya membantu siswa untuk meningkatkan penyesuaian sosialnya dapat dilakukan dengan bermacam-macam bentuk layanan diantaranya dengan kegiatan konseling.

Dalam kasus ini penulis menganggap pendekatan bimbingan yang selama ini berlangsung kurang sesuai dengan peningkatan penyesuaian sosial, oleh karena itu melalui penelitian ini akan dicoba digunakan teknik bimbingan kelompok dengan beberapa perubahan yang akan dilaksanakan pada saat penelitian.

Studi pendahuluan peneliti lakukan dengan melakukan observasi terhadap data kehadiran siswa, catatan kedisiplinan siswa, wawancara dengan guru mata pelajaran, pembina ekstrakurikuler, pembina osis (kesiswaan), serta observasi hasil analisis daftar cek masalah dan kebutuhan siswa, bahwa siswa kelas IX-E SMP Negeri 1 Wonoasri dalam kurun waktu bulan Juli, Agustus, dan awal September 2011 (awal semester pertama) diperoleh gambaran sebagai berikut.

1. Siswa kelas IX- E semuanya pernah melakukan pelangaran tata tertib sekolah, sebagian besar dilakukan oleh siswa laki-laki.

2. Sebesar $30 \%$ siswa kelas IX-E datang terlambat ke sekolah,

3. Berdasarkan data cek masalah dan kebutuhan siswa (IKMS) bahwa sebanyak 5 orang menyatakan:

a) Tidak tahu kultur yang berlaku di sekolah sebanyak 5 orang

b) ragu apakah disekolah masih ada sikap gotong royong sebanyak 34 orang.

c) Kurang mengetahui organisasi yang ada di sekolah sebanyak 25 orang

d) Kurang mengetahui jenis kegiatan perayaaan yang ada di sekolah sebanyak 5 orang

4. Menurut pembina kesiswaan bahwa hanya sebagian dari siswa kelas IX-E yang aktif mengikuti kegiatan ekstrakurikuler.

5. Sedangkan berdasarkan laporan dari guru mata pelajaran sebagian siswa kurang memiliki tanggung jawab terhadap tugas yang diberikan guru 
kepada siswa yakni hanya sebagian siswa yang mengerjakan tugas atau PR yang diberikan guru.

Beberapa indikasi dari masalah yang dialami siswa tampak bahwa ada siswa yang hanya berhasil dalam sebagian mata pelajaran tetapi gagal dalam mata pelajaran lainnya. Banyak siswa yang belajar tanpa konsentrasi, minat belajar rendah. Usaha yang rendah dalam mencapai prestassi belajar. Di sisi lain banyak juga siswa yang mengalami kesulitan dalam menentukan cita-citanya.

Salah satu tujuan layanan bimbingan dan konseling di SMP ialah membantu siswa untuk mengatasi hambatan-hambatan dalam pencapaian tugas perkembangan, yakni tugas perkembangan pada masa remaja. Adanya kesulitan yang dialami siswa SMP dalam mencapai tugas perkembangannya alasannya karena pelayanan bimbingan dan konseling yang telah diberikan guru pembimbing di sekolah selama ini belum banyak membantu. Hal ini bukan hanya disebabkan dari tenaga pelaksana itu sendiri melainkan lebih bayak ditentukan oleh isi, proses, dan teknik layanan yang diberikan guru pembimbing. Apakah kegiatan layanan bimbingan yang diberikan guru telah sesuai atau belum dengan kebutuhan dan harapan siswa.

Tugas perkembangan pada masa remaja meliputi pencapaian dan persiapan yang berhubungan dengan masa dewasa yaitu mencapai hubungan yang lebih matang dengan teman sebaya yang berbeda jenis kelamin, mencapai peranan sosial sebagai pria atau wanita, serta keinginan menerima dan mencapai tingkah laku sosial yang bertanggung jawab.

Dilihat dari tugas-tugas perkembangannya siswa-siswa SMP memiliki ciri salah satunya ialah suka berkelompok terutama dengan teman sebaya. Di dalam kelompok, mereka dapat mengembangkan dirinya. Jika kelompok teman sebaya itu dikelola dengan baik kemungkinan hal itu akan berkontribusi positif terhadap pengembangan diri remaja khususnya. Dengan demikian layanan bimbingan dan konseling di SMP dapat memanfaatkan situasi kelompok ini sebagai media untuk memberikan bantuan kepada remaja. 
Berdasarkan dari uraian di atas, maka peneliti merasa tertarik untuk meneliti yang dirumuskan sebagai berikut "Apakah layanan bimbingan kelompok dapat meningkatkan penyesuaian sosial siswa di sekolah?"

\section{Metodologi Penelitian}

Secara konseptual penelitian ini membahas tentang layanan bimbingan kelompok dan kemampuan penyesuaian sosial siswa. Sedangkan secara kontekstual penelitian ini dilakukan terhadap 30 orang siswa kelas IX-E SMP Negeri 1 Wonoasri Kabupaten Madiun. Terdiri atas 18 orang siswa laki-laki dan 12 orang siswa perempuan. Penelitian ini dilaksanakan mulai bulan September dan berakhir pada bulan November 2011dengan menggunakan metode penelitian tindakan kelas atau (Classroom Action Research). Dengan penelitian ini, diharapkan guru pembimbing dapat dengan mudah mengidentifikasi masalah yang dialami siswa berdasarkan gejala-gejala yang nampak sehingga dapat membantu siswa mengembangkan kemampuan penyesuaian sosialnya. Penelitian ini direncanakan akan dilaksanakan dalam dua siklus. Siklus pertama yang akan dilaksanakan dalam dua 2 kali pertemuan. Siklus kedua dilaksanakan berdasarkan hasil referensi terhadap siklus pertama, siklus ini dilaksanakan sebanyak 2 kali pertemuan juga. Setelah siklus kedua selesai dan direflesikan hasil keseluruhan penelitian akan dilaporkan.

\section{Pengumpulan Data}

Teknik pengumpulan data adalah teknik non tes yaitu observasi dan pengisian angket. Observasi dilakukan terhadap anggota kelompok saat bimbingan kelompok berlangsung oleh tiga observer yang telah ditentukan. Adapun alat pengumpul data yang dipergunakan adalah pedoman observasi. Data kemampuan penyesuaian sosial siswa diperoleh dari hasil penyebaran angket yang telah disusun sebanyak 111 item dengan 2 option pilihan Ya atau Tidak. Angket penyesuaian sosial digunakan sebagai pembanding data observasi. 


\section{Indikator Kinerja}

Adapun indikator kinerja yang diharapkan muncul adalah berupa aktivitas siswa dalam bimbingan kelompok. Setelah bimbingan kelompok dilaksanakan diharapkan siswa memiliki:

1) Pemahaman atas permasalahan yang dihadapi antara lain:

a) memahami topik yang dibahas, dan

b) dapat kerjasama antar anggota kelompok.

2) Tampilan kemampuan siswa yang diharapkan dalam pelaksanaan bimbingan kelompok yaitu sebagai berikut.

a) terbinanya keakraban,

b) keterlibatan dalam suasana kelompok,

c) ketaatan dalam mematuhi aturan kelompok,

d) keterlibatan dalam seluruh kegiatan kelompok,

e) kebebasan berkomunikasi,

f) keinginan membantu anggota lain.

\section{Prosedur Penelitian}

Penelitian yang dilakukan penulis adalah penelitian tindakan kelas. Penelitian dilakukan peneliti selaku guru pembimbing di SMP Negeri 1 Wonoasri. Penelitian tindakan ini dikemas dalam dua siklus dengan tahapan setiap siklus terdiri atas perencanaan (planning), tindakan (acting), pengamatan (observing), dan refleksi (reflecting). Adapun prosedur penelitian yang dilakukan peneliti seperti digambarkan dalam bagan berikut ini. 


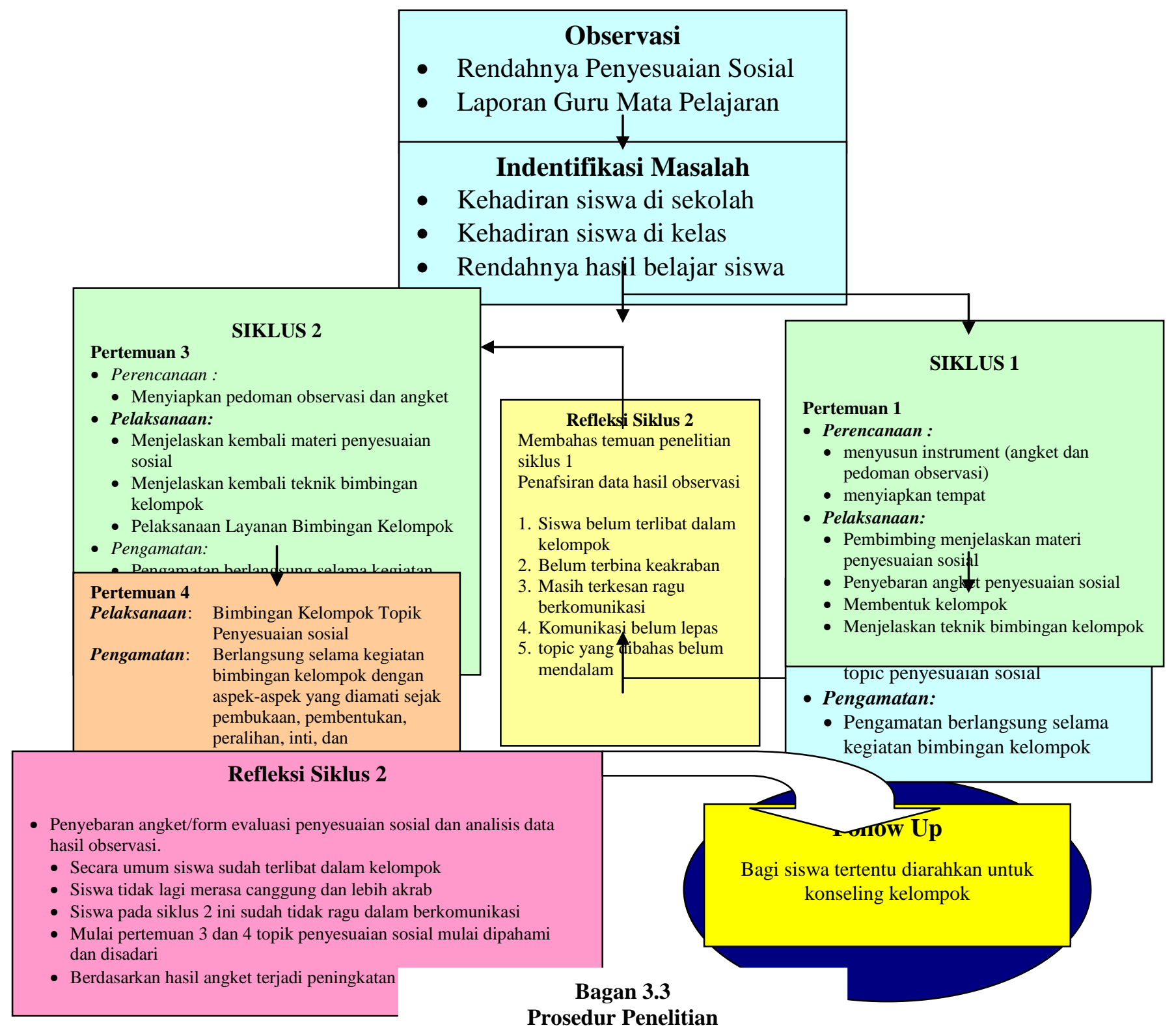

\section{Pembahasan}

\section{Deskripsi Kondisi Awal}

Dari studi pendahuluan di SMP Negeri 1 Wonoasri Kabupaten Madiun masalah yang banyak dijumpai akhir-akhir ini adalah masalah pelanggaran tata tertib sekolah, kecenderungan datang terlambat, rendahnya prestasi yang dicapai siswa, menurunnya gairah belajar yang disebabkan masalah-masalah pribadi yang tidak dapat mereka atasi, sebagian siswa acuh tak acuh dalam mengikuti pelajaran. Perilaku-perilaku siswa di atas dapat dijadikan indikator bahwa mereka tidak 
mampu menyesuaikan diri dengan lingkungannya. Apabila hal ini dibiarkan, akan menghambat proses perkembangan diri dan perwujudan diri yang bermakna sesuai dengan tujuan pendidikan.

Beberapa indikasi dari masalah yang dialami siswa tampak bahwa ada siswa yang hanya berhasil dalam sebagian mata pelajaran, gagal dalam mata pelajaran lainnya, banyak siswa yang belajar tanpa konsentrasi, minat belajar yang rendah, usaha yang rendah dalam mencapai prestasi belajar. Di sisi lain banyak juga siswa yang menemukan kesulitan dalam memilih jurusan yang akan dimasukinya atau program studi yang akan dipilihnya pada pendidikan lanjutan setelah SMP mau meneruskan ke SMA atau SMK. Mereka berbondong-bondong datang ke ruang bimbingan untuk meminta bantuan guru pembimbing. Beberapa siswa menghadapi masalah pribadi dan sosial seperti cemas saat menghadapi ujian, kurang berani mengambil keputusan, sering membuat keributan, melanggar tata tertib sekolah (rambut gondrong, rok pendek bagi perempuan, baju tidak dimasukkan), kurang berani berbicara di depan umum, atau merasa diasingkan teman.

\section{Deskripsi Siklus Pertama}

Penelitian ini direncanakan di berdasarkan prosedur dan tahapan penelitian sebagai berikut.

\section{Perencanaan}

a. Tahapan Persiapan (Orientasi dan Observasi)

Pada tahapan persiapan ini peneliti melakukan hal-hal berikut ini.

1. Mendiskusikan metode, model bimbingan dan instrumen penelitian

2. Peneliti dan guru pembimbing lain yang ada di SMP Negeri 1 Wonoasri membahas skenario bimbingaan yang akan dilaksanakan dalam tindakan bimbingan, disusun berdasarkan data hasil observasi terhadap kegiatan bimbingan penyesuaian sosial siswa.

3. Mengadakan diskusi untuk saling bertukar pikiran dan pendapat dalam merancang bimbingan diri siswa, yang meliputi kehadiran siswa dan 
di kelas, merancang alat evaluasi atau instrumen yang sesuai dengan yang akan di berikan kepada siswa, sehingga setiap hasil bimbingan dapat direfleksi.

4. Membahas masalah yang terjadi akhir-akhir ini yang melibatkan beberapa siswa dari kelompok (lingkungan) yang berbeda. Dan rancangan bimbingan yang akan dilaksanakan oleh peneliti di kelas IX-E SMP Negeri 1 Wonoasri.

\section{b. Persiapan Pratindakan}

Dalam persiapan pratindakan, peneliti membahas rencana kegiatan penelitian tindakan kelas (PTK) di kelas IX-E sebagai informasi bagi siswa dalam kaitannya meningkatkan penyesuaian sosial siswa. Dalam kegiatan ini peneliti melakukan beberapa hal sebagai berikut.

1. menentukan kegiatan bimbingan kelompok sebagai pendekatan yang akan digunakan dalam penelitian ini dengan tujuan untuk membantu siswa yang tidak belum mampu mengembangkan penyesuaian sosialnya dengan baik.

2. Menentukan Waktu yang dibutuhkan untuk penelitian tindakan kelas ini selama 3 bulan dari bulan September 2011 sampai November 2011.

3. Menentukan tempat penelitian Kelas IX-E SMP Negeri 1 Wonoasri

\section{c. Pelaksanaan Tindakan (Siklus Pertama)}

Pelaksanaan penelitian tindakan kelas (PTK) ini dirancang dua siklus dengaan pertimbangaan akan ditindak lanjuti dengan bimbingan kelompok. Pada siklus pertama di rancang melaksanakaan dua kali tindakan bimbingan, dan pada siklus ke dua dilaksanakaan dua kali tindakan dan dalam setiap siklus tindakan kegiataan bimbingan di observasi oleh tiga observer.

Kegiataan bimbingan pada siklus pertama meliputi kegiatan-kegiatan sebagai berikut. 


\section{a) Pertemuan Pertama}

Kegiatan utama pada tahap ini memacu siswa untuk memahami konsep dirinya sehingga akan timbul penyesuaian sosial yang kuat untuk mewujudkan konsep dirinya sehingga dapat hidup secara teratur. Pendahuluan kegiatan penelitian di kelas, peneliti menyampaikan penjelasan tentang maksud dan tujuan yang terkandung dalam penelitiaan ini, dengan demikian pelaksanaan penelitian diharapkan dapat berlangsung mencapai tujuan utama yaitu membantu para siswa untuk meningkatkaan penyesuaian sosial.Kondisi awal siswa Kelas IX-E SMP Negeri 1 Wonoasri diungkap melalui pelaksanaan tes (instrumen) yang telah disiapkan, siswa di ungkap sejauhmana tingkat penyesuaian sosial dari hasil tes tersebut (daftar pertanyaan yang terdiri dari 111 pertanyaan).

Untuk menggambarkan rangkaian aktivitas dalam pertemuan satu dapat diuraikan sebagai berikut.

1. Menyusun instrumen penyesuaian sosial siswa

2. Menyusun satuan layanan bimbingan konseling dengan tema penyesuaian sosial untuk siklus 1 dan siklus 2 .

3. Guru Pembimbing membentuk 3 kelompok dari keseluruhan jumlah siswa sebanyak 30 orang

4. Menyebarkan angket, yaitu untuk mengetahui sejauhmana siswa memiliki penyesuaian sosial dalam mematuhi semua aturan yang ada di sekolah dan sejauhmana penyesuaian sosial siswa dalam belajar dirumah dan dinggap menjadi masalah di sekolah.

5. Mengingatkan kembali siswa tentang pentingnya kemampuan penyesuaian sosial siswa di SMP Negeri 1 Wonoasri .

6. Memberi arahan kepada siswa tentang berbagai upaya yang dapat dilakukan untuk meningkatkan kemampuan penyesuaian sosial siswa di sekolah.

7. Menjelaskan teknik pelaksanaan layanan bimbingan kelompok kepada siswa. 


\section{b) Pertemuan Kedua}

Pertemuan kedua mulai pelaksanaan layanan bimbingan Kelompok; kegiatan bimbingan kelompok diselenggarakan bergiliran karena kelas IX-E terbagi ke dalam tiga kelompok. Masing-masing kelompok mendapat jatah waktu sekitar 45 menit. Peneliti memberikan stimulus/rangsangan untuk memancing siswa dalam mengemukakan pendapatnya tentang penyesuaian sosial dan memberikan contoh-contoh didalam kehidupan sehari-hari siswa selaku pelajar.

\section{Pengamatan}

Pelaksanaan Layanan Biimbingan kelompok ini diamati oleh tiga orang observer Hasil pengamatan dari observer akan dijadikan bahan diskusi oleh penelitian dan observer akan dijadikan acuan untuk membuat rencana tindakan siklus2.

Berdasarkan pengamatan peneliti mendapat gambaran sejauhmana siswa dapat memaknai penyesuaian sosial melalui sikap dan tingkah laku selama kegiatan bimbingan kelompok berlaangsung. Kemudian peneliti mendapatkan gambaran tentaang pemahaman siswa mengenai kemampuan penyesuaian sosialnya..

\section{Refleksi Tindakan pada Siklus Pertama}

Hal-hal yang diberi penguatan dan dijelaskan lebih rinci oleh peneliti adalah hal-hal yang dilakukan siswa atau cara berfikir siswa dan berprilaku sesuai sesuai aturan yang ada di sekolah dan masyarakat. Berdasarkan hasil observasi dapat diketahui secara umum bahwa sebagian siswa belum menunjukkan keterlibatannya dalam kegiatan kelompoknya. Hal tersebut diakibatkan belum terbinanya keakraban antar anggota. Disamping itu masing-masing anggota masih ragu untuk menyampaikan pendapatnya masing-masing. Kenyataan ini disebabkan topik yang dibahas belum dikuasai secara mendalam oleh setiap anggota kelompok. Sebelum kegiatan diakhiri, peneliti menugaskan siswa untuk mencari data dan informasi tentang 
pentingnya kemampuan melakukan penyesuaian sosial melalui diskusi dengan teman, orang tua maupun dengan lingkungan.

\section{Deskripsi Siklus Kedua}

\section{Pertemuan Pertama}

\section{a. Perencanaan}

Pada tahap ini peneliti menyiapkan bahan berupa pedoman observasi dan format evaluasi layanan bimbingan kelompok. Kemudian mempersiapkan materi penyesuaian sosial.

\section{b. Pelaksanaan}

Pada tahap ini peneliti mengawali pertemuan dengan

1) membahas hasil observasi kegiatan pertemuan 1 dan 2 pada siklus pertama

2) Menyempaikan materi penyesuaian sosial

3) Menjelaskan teknis pelaksaaan layanan bimbingan kelompok kepada siswa sebagai review dan refleksi kegiatan siklus 1

Setelah selesai menyampaikan materi dan menjelaskan kembali teknik layanan bimbingan kelompok selanjutnya siswa bergabung kembali dengan kelompoknya untuk melaksanakan layanan bimbingan kelompok seperti pada siklus 1. Setiap siswa kembali masuk dan bergabung dalam kelompoknya. Secara bergiliran dengan dipimpin oleh peneliti (guru pembimbing) kembali menyelenggarakan bimbingan kelompok dengan topik masalah penyesuaian sosial siswa. Anggota kelompok diberikan waktu untuk memaparkan pemahamannya masing-masing berdasarkan pengalaman dirinya tentang kemampuan penyesuaian sosial.

\section{c. Pengamatan}

Pengamatan berlangsung selama kegiatan bimbingan kelompok dengan aspek-aspek yang diamati sejak pembukaan pembentukan, peralihan, inti, dan pengakhiran. 


\section{Pertemuan Kedua}

a. Pelaksanaan

Pada pertemuan kedua ini siswa diberi kesempatan untuk melakukan bimbingan kelompok kembali. Siswa diharapkan dapat membahas kembali kembali apa saja yang dipahaminya tentang penyesuaian sosial yang menjadi topik bahasan selama ini. Akhir dari pertemuan ini siswa mengisi format evaluasi berupa angket penyesuaian sosial yang sama dengan format pada siklus pertama

b. pengamatan

Pengamatan berlangsung selama kegiatan bimbingan kelompok dengan aspek-aspek yang diamati sejak pembukaan, pembentukan, peralihan, inti, dan pengakhiran.

\section{Refleksi Tindakan Siklus Kedua}

Berdasarkan data hasil observasi dan angket/format evaluasi yang disebarkan selama pelaksanaan tindakan pada siklus 2 dapat diketahui kemajuan siswa dalam hal sebagai berikut.

a) Secara umum siswa sudah terlibat dalam kelompok

b) Siswa tidak lagi merasa canggung dan lebih akrab

c) Siswa pada siklus 2 ini sudah tidak ragu dalam berkomunikasi

d) Mulai pertemuan 3 dan 4 topik penyesuaian sosial mulai dipahami dan disadari

Adapun berdasarkan jawaban yang diberikan siswa pada angket terakhir terlihat perubahan pemahaman siswa ke arah yang lebih baik tentang penyesuaian sosial walaupun masih saja siswa yang yang belum menunjukan perubahan yang lebih baik. Hal ini terlihat juga pada saat salah satu siswa dalam menguraikan pemahamannya tentang materi yang dibahas dan dari komentar yang diberikan oleh kawan-kawannya. Secara umum hasil pengamatan observer menyatakan kegiatan bimbingan yang dilaksanakan pada pertemuan terakhir ini sudah cukup. 


\section{Pembahasan Tiap Siklus}

Secara keseluruhan siswa kelas IX.-E SMP Negeri 1 Wonoasri memahami manfaat penyesuaian sosial bagi kehidupannya sehari-hari terutama bagi statusnya sebagai seorang pelajar, walaupun peningkatan pemahaman dari setiap siswa tidak merata. Ada kemungkinan keadaan ini disebabkan oleh tidak adanya kemauan dari yang bersangkutan untuk meningkatan penyesuaian sosial atau permasalahannya yang dialami lebih pelik dari teman-temannya dalam kehidupan pribadinya. Hal lain yang dapat menyebabkan perbedaan ini adalah upaya untuk mengubah perilaku psikologis tidak dapat dilihat langsung setelah proses itu dilaksanakan, perlu waktu yang lama sejalan dengan kematangan kepribadian masing-masing siswa.

Berdasarkan hasil evaluasi pada siklus pertama baik hasil observasi maupun format evaluasi berupa hasil angket penyesuaian sosial siswa diperoleh data atau profil kemampuan penyesuaian sosial siswa kelas IX-E SMP Negeri 1 Wonoasri yaitu sebesar 25,22\% siswa memiliki kemampuan untuk melakukan hubungan interpersonal dengan teman, guru, dan staf tata usaha. Sebesar 44,35\% siswa memeliki kemampuan menyesuaikan dengan tata tertib sekolah. Sebesar 40,11\% siswa memiliki kemampuan berpartisipasi dalam kelompok belajar. Sebesar 40,11\% siswa memiliki kemampuan berpartisipasi dalam kegiatan ekstrakurikuler. Sedangkan sebesar $44,78 \%$ siswa memiliki kemampuan menjaga nama baik sekolah.

Setelah siswa mendapatkan perlakuan pada siklus kedua berupa penguatan pemahaman melalui kegiatan bimbingan kelompok, diperoleh data yang menunjukkan adanya perubahan pemahaman tentang dalam hal penyesuaian sosialnya.

Sedangkan berdasarkan hasil evaluasi yang diambil berdasarkan angket yang diisi oleh siswa setelah dilakukan bimbingan kelompok pada siklus 2 dapat dideskripsikan yaitu sebesar 51,13 \% siswa menyatakan kemampuan untuk melakukan hubungan interpersonal dengan teman, guru, dan staf tata usaha. sebesar $61,37 \%$ siswa sanggup untuk mentaati tatatertib/peraturan sekolah.sebanyak 58,47\% siswa memiliki kemampuan berpartisipasi dalam 
kelompok belajar. sebesar $74,40 \%$ siswa memiliki kemampuan untuk berpartisipasi dalam kegiatan ekstrakurikuler. sebesar 53,35\% siswa memiliki kemampuan menjaga nama baik sekolah.

Skor penyesuaian sosial yang diperoleh pada siklus pertama dan siklus kedua, dapat digambarkan pada tabel di bawah ini.

\begin{tabular}{|l|l|c|c|c|}
\hline No & \multicolumn{1}{|c|}{ INDIKATOR } & $\begin{array}{c}\text { Skor } \\
\text { Siklus I }\end{array}$ & $\begin{array}{c}\text { Skor } \\
\text { Siklus II }\end{array}$ & Selisih \\
\hline 1 & $\begin{array}{l}\text { siswa memiliki kemampuan untuk melakukan } \\
\text { hubungan interpersonal dengan teman, guru, } \\
\text { dan staf tata usaha }\end{array}$ & $25,22 \%$ & $51,13 \%$ & $25.91 \%$ \\
\hline 2 & $\begin{array}{l}\text { Siswa memeliki kemampuan menyesuaikan } \\
\text { dengan tata tertib sekolah. }\end{array}$ & $44,35 \%$ & $61,37 \%$ & $17.02 \%$ \\
\hline 3 & $\begin{array}{l}\text { siswa memiliki kemampuan berpartisipasi } \\
\text { dalam kelompok belajar }\end{array}$ & $40,11 \%$ & $58,47 \%$ & $18.36 \%$ \\
\hline 4 & $\begin{array}{l}40,11 \% \text { siswa memiliki kemampuan } \\
\text { berpartisipasi dalam kegiatan ekstrakurikuler }\end{array}$ & $40,11 \%$ & $74,40 \%$ & $34.29 \%$ \\
\hline 5 & $\begin{array}{l}\text { siswa memiliki kemampuan menjaga nama } \\
\text { baik sekolah. }\end{array}$ & $44,78 \%$ & $53,35 \%$ & $8.57 \%$ \\
\hline
\end{tabular}

\section{Tabel 4.2}

\section{Perkembangan Penyesuaian Sosial dari Siklus 1 ke Siklus 2}

\section{Kesimpulan}

Setelah penelitian tindakan kelas (Classroom action research) di kelas IX-

E SMP Negeri 1 Wonoasri selesai dilaksanakan dapat ditarik beberapa kesimpulan tentang penyesuaian sosial siswa kelas IX-E SMP Negeri 1 Wonoasri, sebagai berikut :

1. Melalui bimbingan kelompok siswa menyadari bahwa untuk melakukan penyesuaian sosial perlu keterlibatan semua pihak.

2. Siswa dapat belajar berempati terhadap lingkungan saat komunikasi terjalin dengan baik.

3. Melalui kegiatan bimbingan kelompok siswa dituntut untuk menyadari betapa penting peranan seorang anggota kelompok dalam menentukan sikap maupun tanggung jawab terhadap sesama anggota kelompok.

4. Siswa kelas IX-E SMPN 1 Wonoasri pada umumnya dapat memahami apa dan bagaimana melakukan penyesuaian sosial terhadap sekolah. 
5. Pada umumnya siswa mengalami kesulitan untuk menerapkan penyesuaian sosial dalam kehidupan nyata sehari-hari setelah diberi contoh-contoh yang nyata tentang kompleknya kondisi lingkungan saat ini.

6. Kegagalan yang dilakukan siswa dalam penyesuaian sosial akibat pemahaman diri atau konsep diri yang rendah, misalnya pada waktu siswa dihadapkan pada pertanyaan-pertanyaan yang harus di jawab secara jujur sesuai dengan dirinya, beberapa siswa kemungkinan besar tidak menjawab secara jujur dan sungguh-sungguh.

7. Kesulitan siswa ditentukan setelah konseling individual pada siswa-siswa yang mempunyai penyesuaian sosial yang rendah.

8. Pada umumnya siswa dapat memahami konsep penyesuaian sosial secara baik, tetapi sangat sulit untuk melaksanakannya karena ada faktor-faktor yang belum terselesaikan secara baik-baik.

\section{SARAN}

Berdasarkan hasil yang telah diperoleh dari pengalaman pelaksanaan penelitian tindakan kelas ini, banyak temuan kami yang tidak dapat disampaikan dalam ruang terbatas ini karena memerlukan waktu yang cukup lama untuk ditindaklanjuti.

Ada beberapa saran yang ingin peneliti sampaikan pada kesempatan ini.

1. Para guru pembimbing hendaknya dapat memahami dan menguasai penggunaan penelitian tindakan kelas karena jenis penelitian ini cukup praktis.

2. para guru pembimbing hendaknya dapat mengakomodasikan teknik-teknik bimbingan yang sesuai agar dalam mengungkap berbagai masalah yang timbul disekolah dilakukan secara efektif dan efisian.

3. Dalam menghadapi era globalisasi saat ini dibutuhkan manusia-manusia yang tangguh yang dapat bersaing dengan baik, oleh karena itu para guru pembimbing diharapkan dapat membantu siswa dalam mengembangkan penyesuaian sosialnya. 


\section{DAFTAR PUSTAKA}

Ali, Mohamad. (1993). Strategi Penelitian Pendidikan. Bandung: Angkasa.

Alhusin, Syahri. (2001). Aplikasi Statistik Praktis Dengan SPSS 10.0, Jakarta : PT. Elex Media Komputindo.

Arikunto, Suharsimi. (1998). Prosedur Penelitian, Jakarta: Rineka Cipta.

Gerungan W.A. (1988). Psikologi Sosial. Jakarta : Eresco.

Hurlock, Elizabeth B., (1992), Psikologi Perkembangan, Suatu Pendekatan Sepanjang

Rentang Kehidupan, (Dit. Istiwidayanti dan Soedjarwo), Jakarta : Erlangga.

Kartono, Kartini, (1993). Kamus Lengkap Psikologi, Jakarta : Rajawali Pers.

Nasution, S (1992), Metodologi Penelitian Naturalistik-Kualitatif, Tarsito Bandung.

Natawidjaja, Rochman. (1987). Pendekatan-pendekatan dalam Penyuluhan Kelompok. Jakarta: P2LPTK Dirjen Dikti Depdikbud.

Nazir, Muhamad. (1988). Metode Riset. Jakarta: Erlangga.

Peraturan Pemerintah No. 29 tahun 1990 tentang Pendidikan Menengah.

Prayitno. (1995). Layanan Bimbingan dan Konseling Kelompok (Dasar dan Profil). Jakarta: Ghalia Indonesia.

Surya, Moh. (1990). Psikologi Perkembangan, Bandung : Jurusan PPB FIP IKIP. . (1991). Dasar-dasar Konseling Pendidikan (Konsep dan Teori). Bandung: Bhakti Winaya.

Syamsuddin Makmun, Abin, (1999), Psikologi Kependidikan, Bandung : Remaja Rosdakarya.

Willis, Sofyan S., (1993), Problema Remaja Dan Pemecahannya, Bandung : Angkasa.

Winkel W. S., (1997), Bimbingan dan Konseling Di Institusi Pendidikan, Jakarta : PT. Gramedia Widiasarana Indonesia. 